DOI https://doi.org/10.18551/rjoas.2018-07.19

\title{
IMPROVEMENT STRATEGY OF EMPLOYEE PERFORMANCE PT. PLN PERSERO AREA GORONTALO
}

\author{
Samudra Anggi Marchilina*, Maarif Ir Syamsul, Affandi Joko \\ School of business, Bogor Agricultural University \\ *E-mail: anggiemarchelina03@gmail.com
}

\begin{abstract}
Every year, the demand for electricity in Gorontalo keeps on increasing, thus requiring PT. PLN (Persero) to always improve the performance of their employees for the company to continue to grow. However, in the year 2016-2017, a decrease in performance was shown at PT. PLN (Persero) Area Gorontalo. Based on these facts, this study wanted to observe the influence of leadership and job satisfaction on employee performance and what strategies are done to improve employee performance in PT. PLN (Persero) Area Gorontalo. The method used in this study is Structural Equation Model (SEM) method with Partial Least Squares (PLS) approach using SmartPLS software and Analytic Hierarchy Process (AHP) method using Expert Choice 11 software. The result of this research shows that leadership style have a significant effect on employee satisfaction but has no significant effect on employee performance, and job satisfaction have a significant effect on employee performance. Then, the proper strategy formulation in order to improve performance is to improve employee prosperity, increase employee competence through employee education and training, improve performance monitoring and evaluation, improve leadership style, and adjustment of employee recruitment.
\end{abstract}

\section{KEY WORDS}

Leadership style, job satisfaction, employee performance, improvement performance

The company needs qualified Human Resources (HR) to run the company's operations properly. Terry (2006) says that humans are the most important and decisive element, the maker of goals and the process actors to achieve the goal, in the absence of human no work process, and an activity always associated with human labor. Therefore it is very important for a company to ensure an improvement in the company's HR performance. Companies that have a very important role and impact for the people of Indonesia is one of the companies incorporated in SOEs. One of the companies incorporated in SOEs is a company engaged in electrical services, namely PT. PLN (Persero), has many branches area in all regions in Indonesia and one of them is PT.

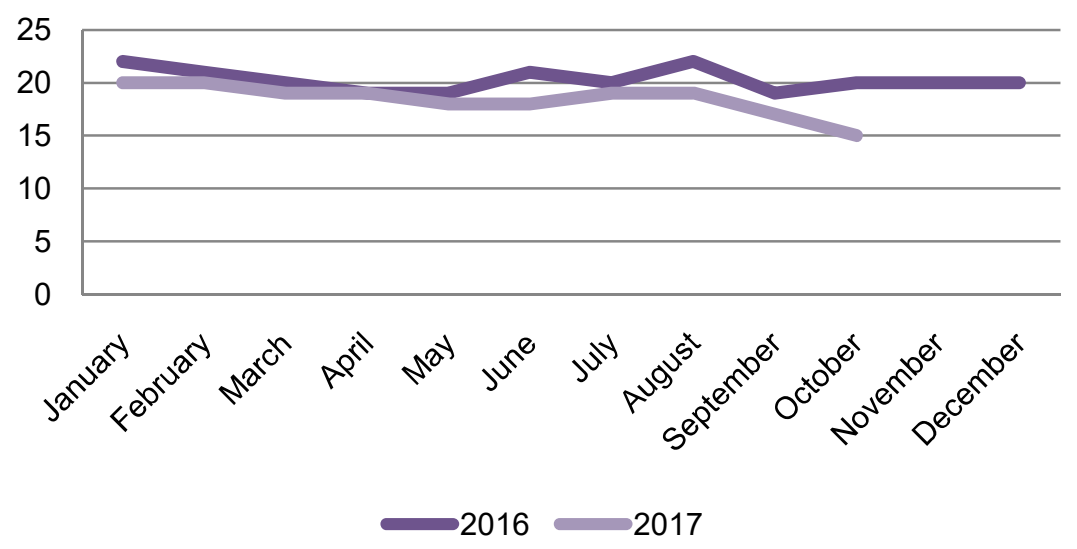

Figure 1 - Graph of performance realization report 2016-2017 
PLN Area Gorontalo. PT. PLN Area Gorontalo is a PLN Service and Network Area that serves the Special Province of Gorontalo, is under the Main Unit of PLN of Region Suluttenggo. Overall PLN Area Gorontalo served by four Rayon namely, Rayon Telaga, Rayon Limboto, Rayon Kwandang, and Rayon Marisa. Every year, the electricity demand in Gorontalo keeps increasing, causing the company to be increasingly demanded to always improve the performance of employees so that the company can keep growing and getting better. But if we look at the performance of PT. PLN (Persero) Area Gorontalo, in the year 2016-2017, showed a decrease in performance realization achieved as illustrated in the following figure 1.

Figure 1 shows that there is a decrease in performance indicators achieved. From a total of 23 indicators, the achievement of network performance achieved has decreased. The fact above shows that there is a decrease in performance at PT. PLN (Persero) Area Gorontalo. Based on these facts, researchers do pre-research to be able to determine exactly what factors affect the decline in performance within the company's environment. From the results of pre-research, shows the factors that dominate as a cause of employee performance decline that is leadership style and job satisfaction. Based on the above facts, this research would like to see the influence of leadership style and job satisfaction on employee performance, and recommendation of what strategy is right to improve employee performance in PT. PLN (Persero) Area Gorontalo.

\section{LITERATURE REVIEW}

Employee Performance. Performance is the result or success rate of a person as a whole over a period of time in carrying out the tasks compared to possible possibilities, such as predetermined standards of work, targets or goals or predetermined criteria (Rivai 2005). According Mangkunegaran (2005) performance (work performance) is the work of quality achieved by an employee in performing their duties in accordance with the responsibilities given. Based on several notions of performance, can be said that the performance is the success of a job obtained or achieved someone in fulfilling their duties and responsibilities to achieve corporate goals.

Employee performance indicators according to Barnard, are as follows:

- Effectiveness and Efficiency. The effectiveness of an organization if the goals of an organization can be achieved in accordance with the planned needs, the efficiency associated with the amount of sacrifices incurred in achieving the goal.

- Authority and Responsibility. In this case the authority is the authority that someone has to govern others (subordinates) to perform tasks assigned to each subordinate within an organization. Responsibility is an inseparable part or as a result of the ownership of such authority. If there is a meaningful authority it automatically arises responsibility.

- Discipline. Discipline when obeying applicable laws and regulations. Employee discipline as the employee's obedience in respecting the employment agreement in which the employee works.

- Initiative. One's initiative is related to thinking power, creativity in the form of ideas for something related to organizational goals. Each reverse initiative gets the attention or positive response from the boss.

Leadership Style. Nawawi (2006) explains that leadership is the ability to convince others to achieve goals enthusiastically through effective cooperation.

Nawawi also explains the leadership function is directly related to the social situation in the life of each group which implies that every leader is inside, not outside the situation. Leaders must strive to be part of the social situation of the group or organization.

According to Nawawi, operational leadership can be divided into five main functions, namely:

- Intruktif function, the leader functions as a communicator determining what (the content of the command), how (how to do the command), when (start time, carry out, report the results), and where (where do the command) so that decisions can be 
realized effectively, so the function of the person being led is simply executing the command.

- Consultative functions, leaders can use the consultative function as a two-way communication. It is used when the leader in an effort to determine decisions that require consideration and consult with the people he leads.

- Function Participation, in running the function of participation, leaders try to activate the people he leads, both in making decisions and in implementing them. Each member of the group has the same opportunity to participate in carrying out the activities outlined in the main tasks, according to their respective positions.

- Delegate function, in performing delegation functions, the leader delegates authority to make or make decisions. The function of the delegate is actually the trust of a leader to a person who is entrusted to delegation of authority by carrying it out responsibly. The function of this delegation must be realized because the progress and development of the group can not be realized by a single leader.

- Control Functions, control functions assume that effective leadership must be able to manage the activities of its members in a direction and in effective coordination, so as to enable the achievement of the goal together maximally. In carrying out the control function, the leader can realize through guidance, direction, coordination, and supervision activities.

Job Satisfaction. Job satisfaction is a pleasant or unpleasant emotional state in which employees perceive their work. Job satisfaction reflects one's feelings toward one's work. This appears in the employee's positive attitude towards work and everything faced in his workplace (Sunyoto, 2012). According to Robbins (2006), job satisfaction refers to the general attitude of an individual to his work. A person with a high level of job satisfaction shows a positive attitude towards the job, someone who is not satisfied with his job shows a negative attitude towards the job.

There are five determinants of job satisfaction called job descriptive index, namely:

- The work itself. The rate at which a job provides fun tasks, learning opportunities, and opportunities to gain responsibility.

- Salary. Job satisfaction is a function of the absolute amount of salary received, the degree to which the salary meets the expectations of the workforce, and how the salary is given.

- Opportunity or promotion. Employees have the opportunity to develop themselves and expand work experience, with the opening of opportunities for promotion.

- Supervisor. The ability of supervisors to provide technical assistance and support behavior. Functional relationships and positive overall relationships provide the greatest level of job satisfaction with superiors.

- Coworkers. Basic human needs for social relationships and fulfilled by co-workers who support employees. If there is a conflict with colleagues, it will affect the level of employee satisfaction with the job.

- System administration and company policy (Mangkunegara, 2005)

\section{METHODS OF RESEARCH}

This research was conducted by taking research setting at PT. PLN Area Gorontalo. The data collection was conducted since February until March 2018. The respondents of this research were all employees of the PT. PLN Area Gorontalo. The method used in the selection of respondents was census method. The number of respondents in research was 158 employees.

Research begins by analyzing the leadership style, job satisfaction, and employee performance in PT. PLN (Persero) Area Gorontalo based on respondent's opinion. Further testing is done to measure the influence of leadership style on employee performance and job satisfaction. Tests are also conducted to measure the effect of job satisfaction on employee performance. Measurement of influence on both variables was done by using 
structural equation modeling (SEM). After that, formulation of strategy will be formulated in order to improve employee performance by using AHP method. By using AHP, employee performance improvement strategy issues will be clearly identified. The results of the analysis are then used as the basis for recommendations for PT. PLN (Persero) Area Gorontalo related to employee performance. The framework of this study can be seen in Figure 2 below:

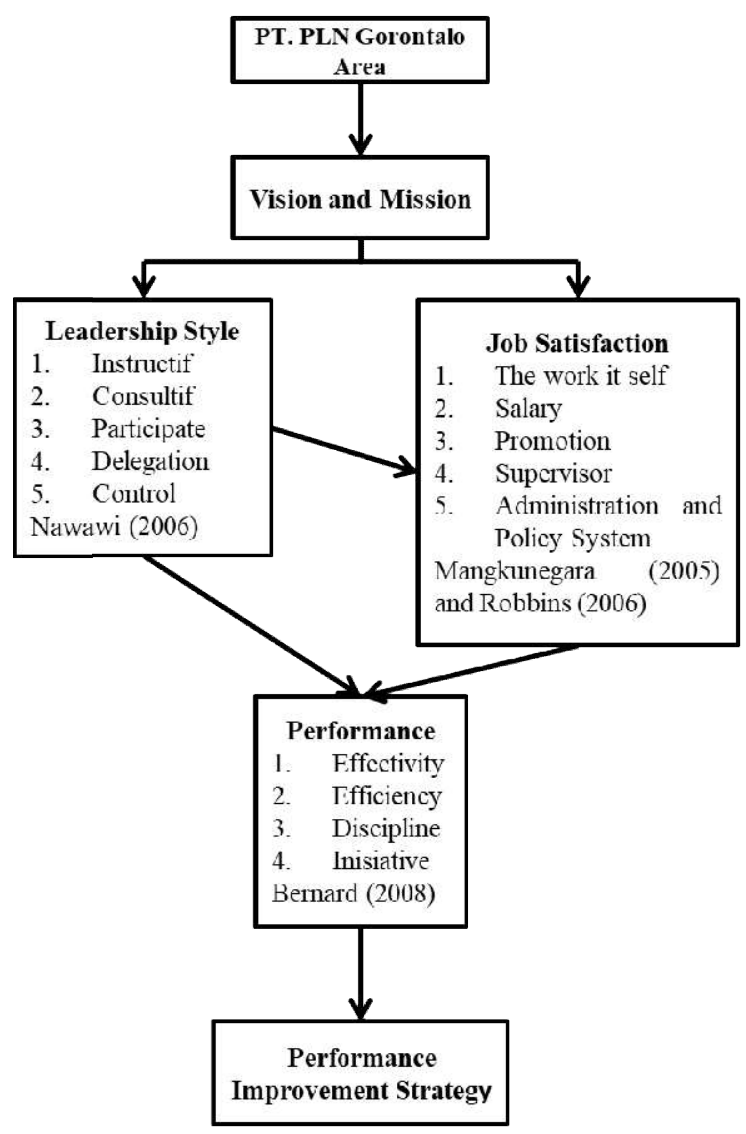

Figure 2 - Conceptual Framework

\section{RESULTS AND DISCUSSION}

General description of respondents describes the characteristics of respondents in this study. This research uses questionnaire distribution method at PT. PLN (Persero) Area Gorontalo to find out how much influence the leadership style and job satisfaction on employee performance. A total of 158 questionnaires were distributed with respondent characteristics including gender, age, duration of work, and last education. Here is an explanation of each respondent's characteristics.

Observations made through the questionnaire obtained the result that the majority of employees are men with percentage $76.1 \%$ and women by $23.9 \%$. According to Anwar (2005) states that the gender effect on employee productivity. PT. PLN is a company that for most of its work requires more male labor than women. Therefore, adjustment in recruitment is very important to be done to adjust the company's need for labor.

The identity of respondents is explained by age, the dominance of respondents is at the age of 20-30 years or 82 percent. This shows that PT. PLN Area Gorontalo has employees in the productive age category so as to facilitate the individual to improve its performance, because it is needed by companies that are looking to grow and maximize the potential of its employees.

Characteristics of respondents then seen from how long employees work in organizations or institutions, the results show that most respondents with a working period of 
$<5$ years of 59 percent. This is understandable because the majority of PT. PLN Area Gorontalo is a young person or fresh graduate. Seeing from the old work that is still fairly new to prove that the lack of experience work most employees. However, because the age of the majority of employees is productive age, it can be overcome by increasing the procurement of employee education and training for employee performance PT. PLN (Persero) Area Gorontalo can increase.

Characteristics of respondents viewed from the level of education, where the level of education in general to become the basis of organization or management to be an important factor to recruit prospective employees in this case is the employee of PT. PLN (Persero) Area Gorontalo. the results showed that most of the respondents had the last education level of Strata 1 (S1) ie 42 percent, then SMA 33 percent and last D3 by 25 percent. This shows the diversity of educational levels that can be an evaluation for the company.

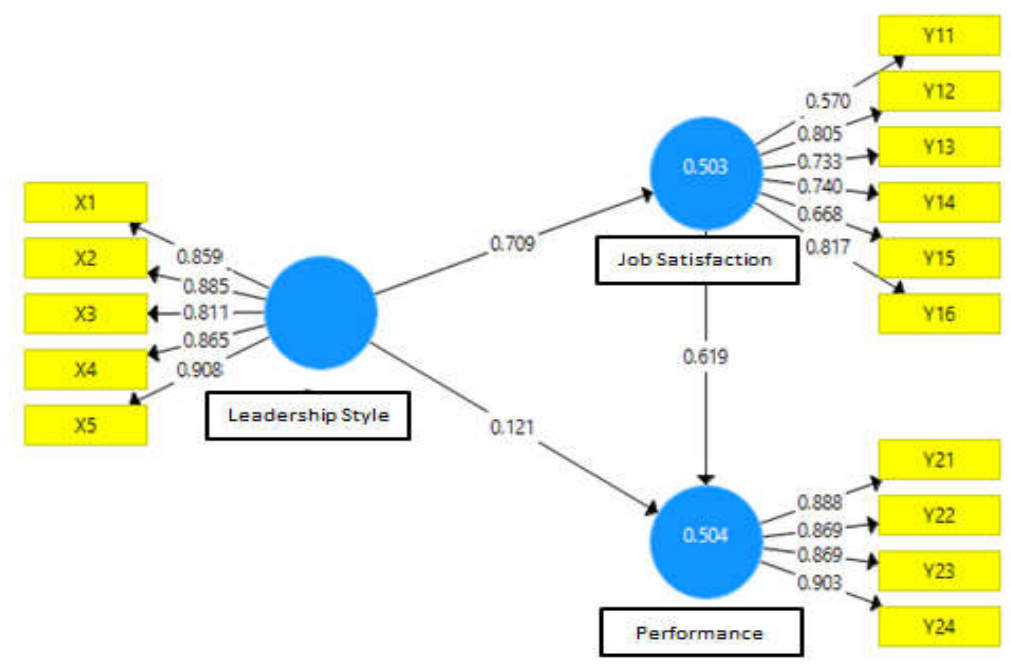

Figure 3 - Processing Results Model

The value that connects the latent variable to the indicator is the value of the loading factor, which is used to test the validity. If the value is $>0.7$ or the value $>0.4$ and the value of AVE $>0.5$, it can be said that the i-th indicator is valid. So, according to Figure 3, there are some indicators of job satisfaction variable $<0.7$, therefore checking the AVE value as shown in Table 1 below.

Table 1 - AVE Value

\begin{tabular}{|c|c|c|c|c|}
\hline $\mathrm{n} / \mathrm{n}$ & Cronbach's Alpha & rho_A & Composite Reliability & Avarage Variance Extracted (AVE) \\
\hline Leadership Style & 0.916 & 0.919 & 0.937 & 0.750 \\
\hline Job Satisfaction & 0.818 & 0.830 & 0.869 & 0.528 \\
\hline Employee Performance & 0.905 & 0.907 & 0.934 & 0.779 \\
\hline
\end{tabular}

Based on table 1 , even though its loading factor value is $<0.7$, it produces AVE value $>0.5$ so it can be considered all indicators are valid. In addition, Test Reliability can be performed with Outer model. Reliability is how far a question can minimize the diversity of answers. Realibility in SEM PLS can be determined by looking at the value of Cronbach's Alpha or Composite Reliability. Both values are greater than 0.7 indicating that the model is reliable.

From the result of measurement of leadership variable in figure 3 shows that indicator X5 (control) has the highest value equal to 0.908 , it can be said that the leader's controlling style to subordinate in job problem and also coordination and monitoring the implementation of work is important and well-valued and have big influence in the assessment employees.

For job satisfaction variable can be seen in Figure 3, indicator Y16 (system administration and company policy) has the highest value equal to 0817 . It can be said that 
the administrative system and company policy is the indicator that most explain the variable of job satisfaction, and judged good by employees.

The latter results show that good performance will create an increase in employee initiatives, responsibilities, and discipline. As in Figure 3, that variable Y24 (initiative) has a high value, that is equal to 0.903 . That is, the most influential indicator in improving performance is to increase employee initiative in their work.

Table 2 - Correlation of variables

\begin{tabular}{|c|c|c|c|}
\hline $\mathrm{n} / \mathrm{n}$ & Leadership Style & Job Satisfaction & Employee Performance \\
\hline Leadership Style & 1.000 & 0.709 & 0.560 \\
\hline Job Satisfaction & 0.709 & 1.000 & 0.705 \\
\hline Employee Performance & 0.560 & 0.705 & 1.000 \\
\hline
\end{tabular}

The size of a strong relationship has a correlation of $>0.5$. Thus, the model created has a fairly strong relationship between variables.

Table 3 - Diversity explained by model viewed from $r$-square value

\begin{tabular}{|c|c|c|}
\hline $\mathrm{n} / \mathrm{n}$ & R Square & R Square Adjusted \\
\hline Job Satisfaction & 0.503 & 0.500 \\
\hline Employee Performance & 0.504 & 0.498 \\
\hline
\end{tabular}

From the value of R-square above, it means leadership style able to explain the diversity of job satisfaction of $50.3 \%$, while the remaining $49.7 \%$ can be explained by other variables outside of the studied. Then job satisfaction and leadership style can explain the diversity of employee performance of $50.4 \%$, while the remaining $49.6 \%$ can be explained by other variables outside of the studied. For ordinal data, this R-square is sufficient.

By looking at the value of path coefficient, can be seen direct influence between variables. The coefficient shows how much change in the response variable if there is a change in the independent variable. The positive coefficient value indicates a direct relationship between the two variables. While the negative coefficient value shows the opposite relationship between the two variables involved.

Table 4 - Correlation of variables

\begin{tabular}{|c|c|c|c|}
\hline $\mathrm{n} / \mathrm{n}$ & Leadership Style & Job Satisfaction & Employee Performance \\
\hline Leadership Style & - & 0.709 & 0.121 \\
\hline Job Satisfaction & - & - & 0.619 \\
\hline Employee Performance & - & - \\
\hline
\end{tabular}

That is, the three variables have a positive relationship. Seen if the direct influence of leadership style on employee performance is very small, it will be seen indirect influence of leadership style variable on employee performance.

Table 4 - Correlation of variables

\begin{tabular}{|c|c|c|c|}
\hline $\mathrm{n} / \mathrm{n}$ & Leadership Style & Job Satisfaction & Employee Performance \\
\hline Leadership Style & - & - & 0.439 \\
\hline Job Satisfaction & - & - & - \\
\hline Employee Performance & - & - & - \\
\hline
\end{tabular}

This value is quite large, so it can be said leadership style indirectly influence (through job satisfaction).

Hypothesis testing. Hypothesis testing is conducted to answer the research objectives:

- HO: The i variable has no significant effect on the response;

- $\mathrm{H} 1$ : The i-variable has a significant effect on the response;

- $\mathrm{H} 0$ rejected when $\mathrm{p}$-value $<0,05$ or thit $>1,96$.

Leadership style has a significant effect on job satisfaction because the value of $t$ arithmetic $>1.96$ or $p$-value $<0.05$. The results showed that leadership had a significant 
positive effect on job satisfaction, which means that the better the leadership, the employee satisfaction will increase

Leadership style has no significant effect on employee performance. This suggests that leadership styles do not have a direct effect on performance, but the style of leadership gives an indirect effect on employee performance through job satisfaction.

Job satisfaction has a significant effect on employee performance. This indicates that the higher the employee job satisfaction, the employee performance will increase.

Test Results AHP Analysis. Preparation of AHP hierarchy compiled and distributed to some respondents who are considered as experts. The respondents numbered eight experts who included among others; two lecturers of tbsp from IPB university, three heads of tbd from state-owned company, three tbsp experts and policy makers in PT. PLN Area Gorontalo. Based on the results of data processing using Software Expert Choice 11, it can be seen the structure of research hierarchy and its scores as shown in Figure 3.

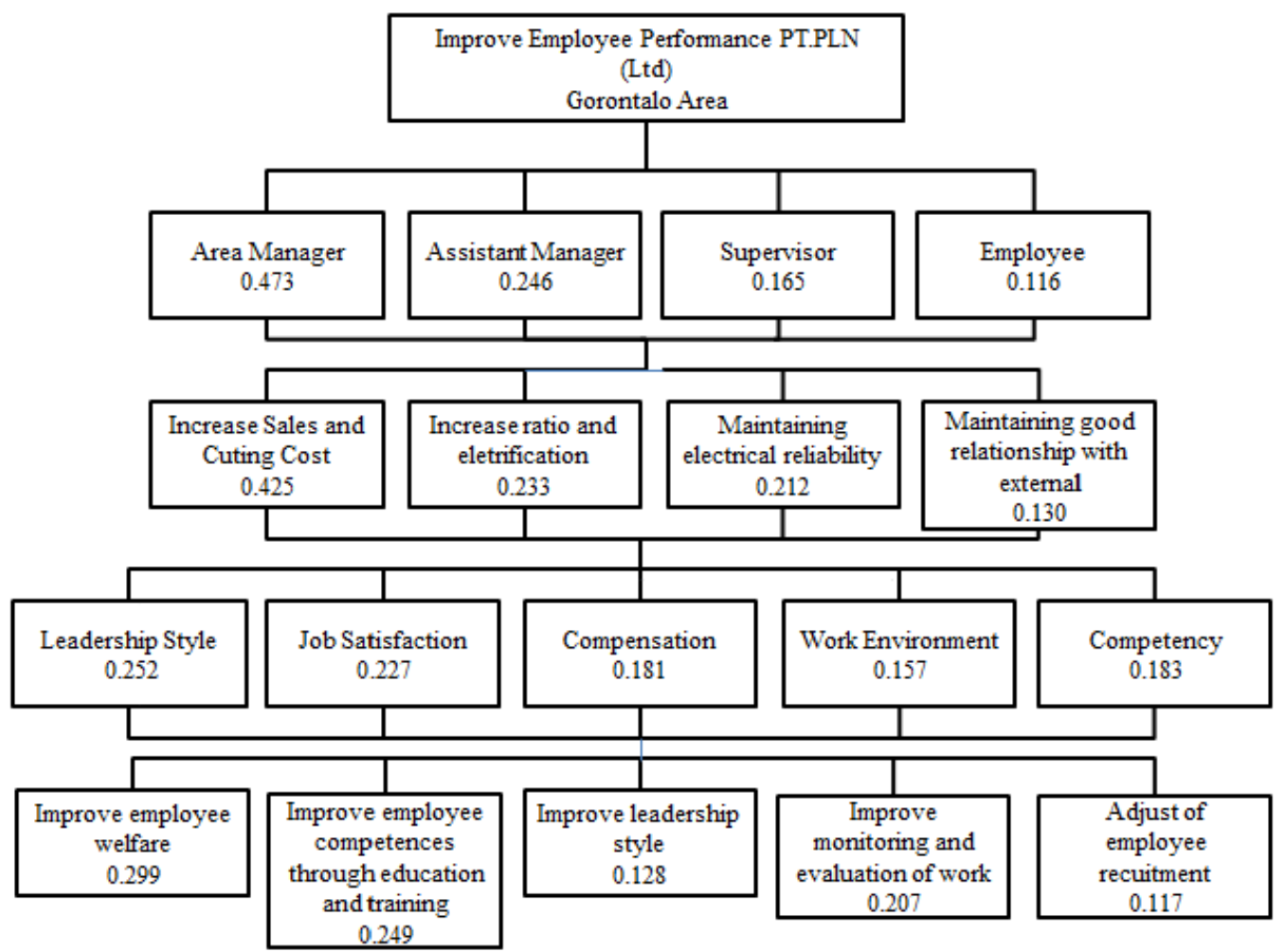

Figure 3 - AHP Analysis Results

Based on the result of synthesis of weight assessment conducted, indicating that the most important strategy and become the main priority in order to improve the performance of employees of PT. PLN Area Gorontalo, is increasing employee well-being (0.299), improving employee competence through employee education and training (0.249), improving monitoring and performance evaluation (0.207), improving leadership style (0.128), and adjusting employee recruitment $(0.117)$ as shown in Figure 3.

Managerial Implications. Based on the results of research then some things that need to be considered by PT. PLN (Persero) Area Gorontalo is:

- Leaders should be more focused and effective in regulating the activities of members in accordance with jobdesk;

- Leaders conduct regular guidance, direction, and supervisory activities to employees;

- Increase employee competence through training and education;

- Company management conducts regular FGD activities involving leaders and employees;

- Improve work monitoring and evaluation. 


\section{CONCLUSION}

The results of this study indicate that leadership style has a significant effect on job satisfaction, but no significant effect on performance, because it has indirect influence through job satisfaction, then job satisfaction has a significant effect on performance. Meanwhile, to improve employee performance PT. PLN. The Gorontalo area, an alternative strategy that can be done is improving employee welfare, improving employee competency through employee education and training, improving performance monitoring and evaluation, improving leadership style, and adjusting employee recruitment.

\section{RECOMMENDATIONS}

Subsequent research, it is advisable to use ANP analysis tools (analitycal network process), and review from different factors such as motivation, discipline and others, and not limited by existing structures and also expand the object of research.

\section{REFERENCES}

1. Barnard, Chester I., 2008, "The Functions of The Executive", Cambridge, Mass Harvard University Press.

2. Ghozali I. 2014. Structural Equation Modeling, Metode Alternatif dengan Partial Least Square (PLS) Dilengkapi software Smartpls 3.0XIstat 2014 dan WarpPLS 4.0 Edisi 4. Semarang (ID): Univaersitas Diponegoro Semarang.

3. Mangkunegara AP. 2005. Manajemen Sumber Daya Manusia Perusahaan. Bandung (ID) : PT. Remaja Rosdakarya.

4. Nawawi H, Martini HM. 2006. Kepemimpinan Yang Efektif. Yogyakarta(ID): Gajah Mada University Press.

5. [PLN] Perusahaan Listrik Negara. 2017. Data Kinerja Perusahaan. Gorontalo(ID): PT. PLN (Persero) Area Gorontalo.

6. Robbins. 2006. Perilaku Organisasi. Jakarta: Salemba Empat.

7. Terry, George R. Prinsip- Prinsip Manajemen. Jakarta: Bumi Aksara, 2006. 